\title{
A holistic method for selecting tidal stream energy hotspots under technical, economic and functional constraints
}

\section{Vazquez, A}

http://hdl.handle.net/10026.1/12108

\author{
10.1016/j.enconman.2016.03.012 \\ ENERGY CONVERSION AND MANAGEMENT
}

All content in PEARL is protected by copyright law. Author manuscripts are made available in accordance with publisher policies. Please cite only the published version using the details provided on the item record or document. In the absence of an open licence (e.g. Creative Commons), permissions for further reuse of content should be sought from the publisher or author. 
This is the author's accepted manuscript. The final published version of this work (the version of record) is published by Elsevier in Energy Conversion and Management 2016 available at: http://dx.doi.org/10.1016/j.enconman.2016.03.012. This work is made available online in accordance with the publisher's policies. Please refer to any applicable terms of use of the publisher.

\title{
A holistic method for selecting tidal stream energy hotspots under technical, economic and functional constraints
}

\author{
A. Vazquez ${ }^{1 *}$, G. Iglesias ${ }^{2}$ \\ ${ }^{1}$ University of Santiago de Compostela, EPS, Hydraulic Eng., Campus Univ. s/n, 27002 Lugo, Spain \\ ${ }^{2}$ University of Plymouth, School of Marine Science and Engineering, Drake Circus, Plymouth PLA 8AA, UK
}

\section{Abstract}

Although a number of prospective locations for tidal stream farms have been identified, the development of a unified approach for selecting the optimum site in a region remains a current research topic. The objective of this work is to develop and apply a methodology for determining the most suitable sites for tidal stream farms, i.e. sites whose characteristics maximise power performance, minimise cost and avoid conflicts with competing uses of the marine space. Illustrated through a case study in the Bristol Channel, the method uses a validated hydrodynamics model to identify highly energetic areas and a geospatial Matlab-based program (designed ad hoc) to estimate the energy output that a tidal farm at the site with a given technology would have. This output is then used to obtain the spatial distribution of the levelised cost of energy and, on this basis, to preselect certain areas. Subsequently, potential conflicts with other functions of the marine space (e.g. fishing, shipping) are considered. The result is a selection of areas for tidal stream energy development based on a holistic approach, encompassing the relevant technical, economic and functional aspects. This methodology can lead to a significant improvement in the selection of tidal sites, thereby increasing the possibilities of project acceptance and development.

Keywords: tidal stream energy; levelised cost of energy; economic map; functional constraints; Bristol Channel.

\footnotetext{
* Corresponding author; email: angela.vazquez@ usc.es; tel.: +34982823295; fax: +34982285926
} 
The European Commission adopted in 2007 the so-called EU climate and energy package, which aims to provide $20 \%$ of the EU's energy consumption through renewable energy sources by 2020 [1].The need for increasing the share of renewable energies in the total energy production has resulted in a growing interest in marine energies - less developed than other renewables at present but with high potential [2]. Among them, tidal stream energy is one of the most predictable and reliable resources [3]. With a number of full scale prototypes in operation [4] and the plans for commercial tidal arrays well advanced [5], this energy has the potential to make significant contributions towards a low carbon energy mix and a green energy economy in a number of areas worldwide, including straits between islands [6], sites in the nearby of headlands [7], or enclosed bodies of water, like estuaries [8]. A case in point is the Bristol Channel - of national strategic significance as the single largest resource area for tidal energy in the UK [9].

The tidal stream resource in the Bristol Channel has been the subject of previous assessments ${ }^{1}$, in which areas with a peak flow velocity in excess of $2.5 \mathrm{~m} \mathrm{~s}^{-1}$ were identified [10]. Predictions about the extraction of this energy suggested that a capacity of $0.6 \mathrm{GW}$ could be installed on the English side of the Outer/Inner Bristol Channel by 2030 [11]. In addition, a further capacity of $0.36 \mathrm{GW}$ would be available around Hartland Point, Lundy and Lands End [12]. The Welsh part, in both in the inner channel and Pembrokeshire, also has an sizeable potential [13], conservatively estimated at up to 0.14 GW of installed capacity [12]. In combination, these studies suggest a total resource of 1.1 GW with at least $0.7 \mathrm{GW}$ in the Outer and Inner Bristol Channel [12].

Notwithstanding, the previous results might exceed the actual potential. Indeed, the theoretical resource can be fundamentally altered by technological [14], economic [15] and 
50 functional constraints - aspects of great relevance that have not been jointly considered so

51 far. Being a young industry, the accurate prediction of the tidal stream energy resource, subject to all the aforementioned constraints, is nevertheless fundamental to attracting investors (both from the public and private sector), boosting the development of this renewable energy through accurate policies [16], and attaining, as a result, grid parity with conventional sources of energy [17]. The challenge for Government and industry is to find ways to harness this energy at an acceptable cost, which maximises the real economic value generated [18] while balancing the impact on other marine users and economic interests [19].

The objective of the present work is to develop a new methodology for selecting tidal stream hotspots and to apply it to a case study, in order to thus show how the potential for tidal energy development can be altered by several constraints - technological, economic and functional. The case study is the Bristol Channel. First, the most energetic areas (with mean spring velocities above $1.5 \mathrm{~m} \mathrm{~s}^{-1}$ ) are identified by means of a hydrodynamics model, calibrated and validated with field data.

Second, the energy that can be harnessed in these areas is computed by means of a geospatial Matlab-based program designed ad hoc, which allows for taking into account the power curve of a specific tidal turbine and in particular, the cut-in and cut-off velocities - the SeaGen turbine is chosen for the case study, but the method can be applied to any turbine [20]. Third, the spatial distribution of the levelised cost of energy (LCOE) is calculated, and areas with LCOE values below $£ 0.25$ per $\mathrm{kWh}$ - the minimum cost to provide adequate returns for investors over a 20 -year period and to maintain momentum in the tidal stream energy sector [21] - are selected as potential tidal sites. The relationship between the LCOE and spatial variables is also investigated, and it is found that water 
depth and distance to shore are two of the main cost drivers in offshore projects. Finally, restrictions due to overlap with other marine uses, such as fishing or shipping are considered. As a result, potential, conflict-free areas for economically viable tidal stream energy exploitation are identified.

The method, which can be applied not only in the Bristol Channel but elsewhere, is a new decision-making tool at the disposal of policy-makers and investors, which can contribute to reducing the economic uncertainties of future tidal stream energy projects, and therefore to the development of marine renewables.

\section{Material and methods}

The methodology herein developed lies in the production of a set of combined results, namely resource assessment, technical potential, spatial distribution of the cost and a freely combinable set of excluding uses. This combination allows for the formulation of scenarios of technological and cost development interlinked with functional constraints that come with tidal stream energy development at a large scale. The methodology has been applied with the data and procedure described below.

\subsection{Data}

The study area is the Bristol Channel (UK), extending from the mouth of the Severn to the Celtic Sea, with the open ocean boundary between St Govan's Head and Trevose Head (Figure 1). The assessment of the tidal stream resource was based on results from a NavierStokes solver with a finite-difference scheme [22]. This allowed for considering not only the spatial variability of the resource, but also its all-important temporal variability, through the tidal cycle. Vertically-averaged expressions of the governing equations 
(conservation of mass, momentum and the transport equation) were used in their baroclinic form (Eqs. 1-3) [23]:

$$
\frac{\partial \zeta}{\partial t}+\frac{\partial[(d+\zeta) U]}{\partial x}+\frac{\partial[(d+\zeta) V]}{\partial y}=Q
$$

where $U$ and $V$ stand for the vertically integrated velocity components in the east $(x)$ and north $(y)$ directions, respectively; $d$ represents the local water depth relative to a reference plane; $Q$ is the intensity of mass sources per unit area; $f$ is the Coriolis parameter, $v_{\mathrm{h}}$ is the kinematic horizontal eddy viscosity, $\rho_{o}$ is the reference density, $\rho^{\prime}$ is the anomaly density, $\tau_{s x}, \tau_{s y}, \tau_{b x}$ and $\tau_{b y}$ are the shear stress components [24]. As regards the Eq.(3), which is the transport equation, $c$ stands for salinity or temperature, $D_{h}$ is the horizontal eddy diffusivity, $\lambda_{d}$ represents the first order decay process, and $R$ is the source term per unit area [25].

Tidal forcing conditions at the open boundary of the model were obtained from the global ocean tide model TPXO 7.2 [26], which proved to produce accurate results in a number of previous works (e.g. [27]). In particular, the sea level was prescribed as a function of time using the following constituents: M2, S2, N2, K2, K1, O1, P1, Q1, M4 (a Dirichlet boundary condition [28]). Salinity and temperature at the Sea Celtic boundary were imposed using data from the British Oceanographic Data Centre [29]. Concerning the land margins, the boundary conditions were free slip (i.e. zero shear stress) and null flow. The 
122 spatial resolution of the model was $0.25 \mathrm{~km}^{2}$, derived from grid cells of $500 \mathrm{~m} \mathrm{x} 500 \mathrm{~m}$.

123 The bathymetry was interpolated onto this grid from the General Bathymetric Chart of the 124 Oceans (GEBCO).

125 The model was run for 50 days, being the first 31 days the spin-up period, which aims to 126 adjust dynamically the flow field so that the initial conditions do not affect the numerical 127 results during the period of interest (a spring neap cycle from 14 March 2011 to 28 March 2011). The initial hydrodynamic conditions were null velocity and surface elevation throughout the grid (cold-start) [30]. The model was validated against measured tide levels at four gauge stations obtained from the UK tide gauge network [29] and tidal stream data at five tidal diamonds from Admiralty Chart No. 1165. A high level of correlation between observed and predicted data was obtained $\left(\mathrm{R}^{2}>0.87\right)[15]$.

Tidal stream technical potential represents the achievable energy generation given system performance and topographic limitations [31]. It was estimated by using a tidal stream energy density map and the bathymetry as spatial inputs, as well as tidal power technology data (e.g. cut-in and cut-off velocities of the turbines) for the calculation of annual energy output.

The density map was obtained throughout the above-mentioned hydrodynamic model (raster-based model). Coupled with a geospatial Matlab-based program, calculations of the technical potential for the entire study area were performed in a continuous manner by taking into account the following assumptions (a-d) (Figure 2):

(a) The number of turbines $n$ per cell was established on the basis of the maximum number that the $0.25 \mathrm{~km}^{2}$ cells can accommodate, considering a lateral distance of 5 
times the rotor diameter and a longitudinal distance of 10 times the rotor diameter [32] disposed in a staggered configuration (Figure 3).

(b) Bathymetry limits rotor diameter $D$. For the study, the diameter was established as 70

$$
E_{t}=0.5 C_{p} \rho A n \int_{t=0}^{t=T_{1}} v(t)^{3} d t
$$

where $C_{p}$ is the power coefficient, $\rho$ is the water density, $n$ is the number of converters, $v(t)$ is the unperturbed fluid velocity $\left(\mathrm{m} \mathrm{s}^{-1}\right.$ ) (vertically averaged velocity in each grid cell), time $t=0$ to time $t=T_{1}$ is the period of time considered (one year) and $A$ is the area swept by one rotor.

\subsection{Tidal stream energy: economic potential}

This part of the methodology aims to obtain the spatial distribution of tidal stream energy costs and the locations that are economically viable for developing tidal stream farms. The LCOE (levelised cost of energy) was used as the fundamental economic parameter [15]; it is the cost of one electricity unit $(\mathrm{kWh})$ produced by a tidal stream energy farm averaged over its entire expected lifetime [34] (estimated at 20 years [35]). The energy potential $\left(E_{t}\right)$ was an input of the LCOE calculation, as shown below

$$
L C O E=\left[\sum_{t=0}^{t=T}\left(C A P E X_{t}+O P E X_{t}\right)(1+r)^{-t}\right]\left[\sum_{t=0}^{t=T}\left(E_{t}\right)(1+r)^{-t}\right]^{-1}
$$


where $r$ is the discount rate, $T$ represents the expected lifetime of the project and CAPEX and OPEX are the capital and operational costs, respectively. The calculations of the LCOE were based on the following assumptions (Figure 2):

(a) Capital expenditures (CAPEX) included the following cost-categories: device costs (including rotor, power train, generator and other equipment ) cable costs, costs of foundations, installation costs and grid connection costs (Figure 4). Costs of foundations, rotor and cable account for $70 \%$ of the total CAPEX [36].

(b) Foundations costs were calculated using water depth as a spatial variable (imported from the hydrodynamic model), as in Serrano et. al., 2015 [37] (Table 1).

(c) Cable costs are mainly estimated on the basis of the exporting cable cost, which is the cable that allows delivering the electricity produced to a land-based electrical substation $[38,39]$. They are highly sensitive to the cable length, which is directly related to the distance to shoreline $(L)$. Table 1 shows the relationship between cable costs and distance to the shoreline, on the basis of [40]. Note that the cable cost equation was used by calculating $L$ as the minimum distance to the shore.

(d) Rotor costs were calculated from the number of turbines $(n)$ and the rotor diameter (D). Table 1 shows the rotor cost equation, obtained on the basis of a feasibility study into tidal current generation in Orkney and Shetland [40], where the rotor costs for a range of different values of the diameter were estimated. [40].

(e) Operational costs were based on the installed power [41] (Table 1).

(f) The distance to the shoreline $(L)$ was calculated as a function of the minimum distance to the shore.

(g) A 20-year technical and economic lifetime was assumed (T).

(h) A $10 \%$ annual discount rate ( $r$ ) was considered [35]. 
191 As a result, the spatial distribution of costs to produce $1 \mathrm{kWh}$ of electricity during the

192 lifetime of the project was obtained for the entire domain.

194 Tidal stream energy requires ocean space, a scarce resource with many competing

195 functions, which may result in user-user and user-environment conflicts that might delay the commercial development of this marine renewable [42]. Different types of functional constraints (legally and practically unfit areas, alternative uses, etc.) could reduce the available space for tidal stream energy deployment in the Bristol Channel. This reduction is mainly due to potential overlaps with alternative marine uses, e.g. submarine cabling, shipping, MoD (ministry of defence) areas and nature conservation agreements (Figure 5).

Other aspects, such as proximity to a land-based electrical substation, can also have an effect on the offshore deployment (Figure 5b).

According to their degree of negotiability, the competing uses can be divided into "hard" and "soft" constraints [43]. MoD and conservation areas are considered hard constraints, since they restrict the deployment of tidal stream energy technology [11] (Figure 5c and 5d). Among the negotiable (soft) constraints is the shipping activity. The Bristol Channel is used as a prominent shipping route as there are a number of large ports located throughout the Bristol Channel and Severn Estuary region. The intensity of annual traffic is between 0-40 vessels, in the areas with the lowest level of traffic (level 1), and up to 10240 vessels (level 5) [44] (Figure 5a). These areas may require the investigation of whether the exact position of a potential tidal farm would conflict with a given shipping route. In particular, the personal communication with the navigation safety branch of the Maritime and 
stream device [45]. Otherwise, there may be objections to a project proposal on the grounds of navigational safety or emergency response preparedness.

216 As regards submarine cabling, there is an opportunity to draw upon the experience of the 217 offshore wind energy sector [44]. If a tidal stream energy farm is to occupy the same or 218 neighbouring areas of seabed that the cables, discussions with the Crown Estate and the consideration of their GIS database are required. However, the deployment of wave and tidal power projects is not directly comparable to the process of installing offshore wind farms, albeit expected to fall under the same legislation. Compared to the offshore wind energy fixed structures, wave and tidal devices vary greatly in design and operation and often include major components easily removed from site and some floating structures [44]. This has an influence in the establishment of the buffer distances to the position of the cables .

Another important factor in any ocean energy project is the need for electrical connection between the generating device and the local grid network [46]. The identifiable ocean energy resource is often situated away from densely populated areas; the resource far outweighs the demand from local communities in many cases. Thus, to be transported to regions where the demand is greater, electrical infrastructure is required. Such an infrastructure is often included as part of the tidal farm project. However, the existence of a grid connection point in the vicinity of the farm, reduces its costs [38] and thus, renders a given area a more interesting tidal stream energy site. A detailed grid analysis is outside the scope of this study, but the existing grid connection points in the English part of the Bristol Channel are presented in Figure 5b. They were used to make a narrower selection of the areas with greater economic viability (Figure 2). 


\section{Results and discussion}

239

240

241

242

243

244

245

246

247

\subsection{Technical potential}

Tidal energy density refers to the flow of kinetic energy per unit swept area of a turbine that is available for conversion into electricity. The annual energy density is a useful way to evaluate the tidal resource available at a potential site, since it is independent of the turbine characteristics. In the Bristol Channel, the annual energy density ranges from 60 to $90 \mathrm{MWh} \mathrm{m}^{-2}$ in the most energetic areas (Figure 6) [15], which are endowed with a significant tidal stream resource. In these areas, mean spring peak velocities are above 2.5 $\mathrm{m} \mathrm{s}^{-1}$, comparable to those in North West Anglesey and South West Scotland [10]. The mid- and inner part of the Bristol Channel present annual energy densities in the range of 20-60 MWh $\mathrm{m}^{-2}$, corresponding to mean spring velocities of $1.5 \mathrm{~m} \mathrm{~s}^{-1}$, similar to those observed in the Shannon Estuary (Ireland) [47] and East Anglia (UK) [48].

The available power in the tidal flow at a site, notwithstanding, cannot be extracted for energy production in its entirety [5]. Limitations such as channel geometry and technical characteristics play a role in the amount of extractable energy [49]. For typical commercial-scale tidal projects at most sites, no more than $30-40 \%$ energy extraction is realised due to Betz law and other limitations, which are accounted for in the power coefficient $\left(C_{p}\right)$ [50]. In this study, the technical potential was obtained as the highest potential level of tidal stream energy generation, based on the overall resource availability (Figure 6), power coefficient and the maximum deployment density of turbines based on functional constraints (see Section 2.2). An example of these considerations is shown in Figure 7 for grid cell $\mathrm{P}$. 
The results (Figure 8) accord well with the energy density map: the highest values of annual energy production AEP coincide with the highest tidal stream energy resource (mid- and east part of the Bristol Channel). Depending on the value of power coefficient $(0.30,0.35$ or 0.40 , in line with the range expected for marine converters [51]) the size of the areas inside a given energy production limit vary; thus, the higher the power coefficient, the higher the amount of energy produced. For example, increasing the power coefficient from 0.30 to 0.40 could increase the areas above $10 \mathrm{GWh}_{\text {year }}{ }^{-1}$ and $20 \mathrm{GWh}$ year $^{-1}$ by a percentage of $\sim 26 \%$ and $\sim 40 \%$, respectively. This is a relevant result, for it shows that resource assessments of a particular area cannot be understood without technical constraints. In this regard, it can be seen that technological development (in the form of an improvement in the power coefficient value, in this case) can enhance the productivity of , and thus, enhance its economic viability for tidal stream energy, since the LCOE is related to the amount of electricity generated.

\subsection{Economic potential}

According to the above cost model, the spatial distribution of LCOE for tidal stream energy was obtained (Figure 9). The costs of tidal stream energy are highly correlated to water depths (Figure 9a), distance to the shoreline (Figure 9b) and tidal resource (Figure 9c). More specifically, the lower the water depths $(d)$, the distance to the shoreline $(L)$ and the higher the tidal power production $\left(E_{t}\right)$, the lower the production costs (LCOE) for tidal stream energy. Least cost areas have LCOE values below $£ 0.25$ per $\mathrm{kWh}$, which is considered a cost that can provide adequate returns for investors over a 20 -year period and maintain momentum in the tidal stream energy sector [21]. They are mainly located within the $0-25 \mathrm{~m}$ water depths (shallow waters), in areas where mean spring peak velocities are mostly above $1.5 \mathrm{~m} \mathrm{~s}^{-1}$. Shallow areas present a number of advantages for first generation 
tidal stream farms. A turbine can be designed to occupy a greater proportion of the vertical water column than it would at deeper sites, and thus capture a larger fraction of the power available in the tidal flow. In addition, shallow waters are normally located nearshore, away from shipping channels [48]. Indeed, areas with LCOE values $<£ 0.25$ per $\mathrm{kWh}$ are located at distances from the shoreline below $10 \mathrm{~km}$ (Figure 9b), in line with the majority of offshore wind energy projects in the UK [52]. The distance to the shoreline is an important parameter in offshore installations, since both cable costs and transmission losses decrease with decreasing distance [39]. Least-cost regions (LCOE values $<£ 0.25$ per $\mathrm{kWh}$ ) represent $24.39 \%$ of the study domain.

Available tidal stream energy with costs between $£ 0.25$ per $\mathrm{kWh}$ and $£ 0.70$ per $\mathrm{kWh}$ is associated with water depths in the range of $25-40 \mathrm{~m}$. Such deep waters impose higher structural requirements which are reflected in their higher cost. These areas are located further than $15 \mathrm{~km}$ from the shoreline, imposing a bigger challenge for the maintenance operations since the weather windows are reduced with the increase of the offshore distance [53]. Mean spring velocities are below $1.5 \mathrm{~m} \mathrm{~s}^{-1}$, which reduces significantly the power production, and increase the unit cost of energy.

The most expensive tidal stream energy areas, with LCOE above $£ 0.70$ per $\mathrm{kWh}$, are located far from the shoreline (aprox. $30 \mathrm{~km}$ ) with water depths above $40 \mathrm{~m}$ and low peak velocities (below $1 \mathrm{~m} \mathrm{~s}^{-1}$ ). In principle, these areas would not be of much relevance for tidal stream energy applications, and therefore could be used for other purposes [5].

\subsection{Functional potential}

Based on previous results, a number of potential tidal stream hotspots were selected (depicted by the black lines in 10). They all have LCOE values below $£ 0.25$ per $\mathrm{kWh}$ 
307 (most economic areas). As explained in the previous section, these areas are in shallow waters, near the shoreline, and have a substantial tidal stream resource (with peak velocities above $1.5 \mathrm{~m} \mathrm{~s}^{-1}$ ). Furthermore, the functional constraints relevant to each area were considered in selecting them ${ }^{2}$. However, depending on the degree of negotiability of such constrains, two groups of potential tidal stream locations were defined: A and B, most and least restrictive constraints, respectively (Table 2). Group A includes four regions: (A1) Hartland Point; (A2) Lynmouth; (A3) Bridgend; and (A4) Watchet, which are conflict-free areas (no overlay with other activities, and a maximum level of shipping intensity traffic of 2: 40-160 vessels per year, Figure 5a). They represent $11.16 \%$ of the economic area (LCOE $<£ 0.25$ per kWh). Shipping activity has an overwhelming impact on the reduction of economic areas, since least-areas cost overlay with the main shipping routes and the highest density of vessels (level 5: 5120-10240 vessels per year) (Figure 5a). The hard constraints, MoD and conservation areas, do not reduce significantly the areas where the resource is substantial (and the cost low), with the exception of the space between Watchet and Bridwater Bay, where the LCOE is $\sim £ 0.25 \mathrm{kWh}$ (Figure 10).

The relaxation of the shipping traffic constraint, e.g. by considering areas with a level of shipping traffic equal or higher than 3 (160-1280 vessels per year), instead of 2, would increase the number of hotspots (group B). The problem is that these level-3-areas are located for the most part in deep water(water depths above 40), which are not the most suitable for building tidal farms under the current technological and economic conditions. These new areas would increase the total size of the hotspots by $6.44 \%$ (over the economic regions). Thus, the surface area of the economic area would represent $17.06 \%$ of the total surface area of the Bristol Channel. 
330 Of all the hotspots, Watchet (A4) has the advantage of being close to a grid substation.

331 Lynmouth is also near to a land grid connection point (at a distance of $\sim 3.5 \mathrm{~km}$ ). This

332 provides an opportunity for early commercial expansion, without increasing the overall

333 grid transmission costs of a future project. At present, not many areas are proximate to a

334 tidal grid substation, which suggests that extension and reinforcement of the network will

335 be required. There are plans for a $400 \mathrm{kV}$ network to be extended from Indian Queens to

336 Hayle by 2020 [11].

\section{4. Conclusions}

Tidal stream energy is a nascent industry, and therefore the accurate prediction of the tidal stream energy resource is fundamental to attracting investors (both from the public and private sector) and boosting the development of this renewable energy. In this work, a new method was developed for selecting tidal stream hotspots in a holistic manner, accounting for technological, economic and functional constraints. The application of the method was illustrated through a case study in the Bristol Channel.

The first step in the method is the analysis of the tidal velocity and its spatial and temporal variability and, on this basis, of the tidal stream resource, leading to a site-specific tidal resource characterisation map of the annual energy density. A numerical hydrodynamics model, calibrated and validated with field data, was used for this analysis.

348 Coupling this model with a geospatial Matlab-based tool, the spatial analysis of the energy production and cost was carried out. In the second step, technical constrains were considered for each grid cell. The maximum turbine size and deployment density was calculated for each site; the power curve of a specific turbine, and in particular its cut-in and cut-off velocities was considered for each velocity series at each point of the domain; and power coefficient values representative of existing specifications for marine current 
converters were included. As a result, the spatial distribution of the energy production was obtained. Such energy production, is an input of the LCOE calculation (third step), together with the estimation of both capital and operational costs. In the calculation of these costs, spatial variables were accounted for. For example, the effects of water depth and distances to the shoreline on foundations and cable costs were included. Finally, leastcost areas were analysed in conjunction with a number of spatial constraints (including shipping and submarine cabling). Areas with competing uses were excluded for the selection of tidal stream energy hotspots.

From the results in the case study two main conclusions can be drawn. First, the assessment of the tidal stream resource itself is insufficient for the purpose of selecting the optimum tidal sites, and must be complemented with data on the cost of producing this energy; for instance, some of the most energetic sites are in water depths that could render a future project inviable. Second, a proper analysis of competing functions of the marine space is fundamental in selecting tidal stream sites. Indeed, the pre-selection of economic areas was substantially modified when potential conflicts with other competing uses were considered. In particular, the inclusion of shipping constraints significantly reduces the areas suitable for tidal stream energy deployment.

To sum up, the method presented, by accounting for site-specific tidal stream variability and the relevant technical, economic and functional constraints, constitutes an aid tool for project developers and policy makers to select suitable areas for tidal stream farms. For project developers this method can contribute to enhancing the economic and consenting viability of the project, thereby reducing the risk of project denial. For policy makers this approach highlights certain aspects for policy development with a view to fostering the tidal stream energy sector in a strategic manner, for instance by promoting spatial planning for areas with potential conflicts between marine space functions. Although the method 
379 was illustrated through its application to a particular area, it can be applied to any region of 380 interest.

381 
383 This work was carried out within the framework of the project "Atlantic Power Cluster", 384 funded by the European Commission through its Atlantic Area Programme. The authors 385 wish to thank the British Oceanographic Data Centre for providing tide gauge records. 386 During this work A. Vazquez has been supported by the FPU grant 13/03822 of the Spanish 387 Ministry of Education, Culture and Sports (Ministerio de Educación, Cultura y Deporte) and 388 by the Barrie Foundation through a grant to undertake a predoctoral fellowship at Plymouth 389 University, UK. 


\section{Footnotes}

$2{ }^{1}$ References of studies on tidal barrage schemes were not included, but can be found in e.g. $3 \quad[54,55]$.

$4 \quad{ }^{2}$ These values of shipping traffic are codified in a data structure (together with the value of 5 the spatial coordinates for each point) and processed by the Matlab-based tool. The tool 6 selects those areas with a level of traffic intensity below 2 (to delimit zones A1 to A4, Figure 7 10) and below 3 (for zones B1 and B2, Figure 10). A similar procedure is followed for the 8 same constraints and in the end, the boundaries of the selected (conflict-free) areas are plotted 9 in Figure 10. 


\section{References}

[1] Gallego-Castillo C, Victoria M. Cost-free feed-in tariffs for renewable energy deployment in Spain. Renewable Energy 2015;81:411-20.

[2] Vicinanza D, Contestabile P, Ferrante V. Wave energy potential in the north-west of Sardinia (Italy). Renewable Energy 2013;50:506-21.

[3] Iglesias G, Sánchez M, Carballo R, Fernández H. The TSE index - A new tool for selecting tidal stream sites in depth-limited regions. Renewable Energy 2012;48:350-7.

[4] Sanchez M, Carballo R, Ramos V, Iglesias G. Energy production from tidal currents in an estuary: A comparative study of floating and bottom-fixed turbines. Energy 2014;77:802-11.

[5] Lewis M, Neill SP, Robins PE, Hashemi MR. Resource assessment for future generations of tidal-stream energy arrays. Energy 2015;83:403-15.

[6] Neill SP, Hashemi MR, Lewis MJ. The role of tidal asymmetry in characterizing the tidal energy resource of Orkney. Renewable Energy 2014;68:337-50.

[7] Neill SP, Jordan JR, Couch SJ. Impact of tidal energy converter (TEC) arrays on the dynamics of headland sand banks. Renewable Energy 2012;37:387-97.

[8] Ramos V, Carballo R, Álvarez M, Sánchez M, Iglesias G. A port towards energy selfsufficiency using tidal stream power. Energy 2014;71:432-44.

[9] Ahmadian R, Falconer RA. Assessment of array shape of tidal stream turbines on hydroenvironmental impacts and power output. Renewable Energy 2012;44:318-27.

[10] Robins PE, Neill SP, Lewis MJ, Ward SL. Characterising the spatial and temporal variability of the tidal-stream energy resource over the northwest European shelf seas. Appl Energy 2015;147:510-22.

[11] PMSS. Offshore Renewables Resource Assessment and Development (ORRAD) Project - Technical Report. Report prepared for South West Regional Development Agency. 2010.

[12] Regen SW. Bristol Channel Energy - A balanced technology approach. Discussion Document. Online:

http://regensw.s3.amazonaws.com/bristol_channel_energy_balanced_technology_approach_2 0121127_c541010d0b3719f8.pdf.

[13] Evans P, Mason-Jones A, Wilson C, Wooldridge C, O'Doherty T, O'Doherty D.

Constraints on extractable power from energetic tidal straits. Renewable Energy 2015;81:70722.

[14] Ramos V, Iglesias G. Performance assessment of Tidal Stream Turbines: A parametric approach. Energy Conversion and Management 2013;69:49-57. 
1 [15] Vazquez A, Iglesias G. LCOE (levelised cost of energy) mapping: A new geospatial tool 2 for tidal stream energy. Energy 2015;91:192-201.

[16] Vazquez A, Astariz S, Iglesias G. A strategic policy framework for promoting the marine energy sector. 3rd IAHR Europe Congress, 2014, Porto - Portugal. ISBN 978- 989-96479-2-3.

[17] Vazquez A, Iglesias G. Grid parity in tidal stream energy projects: An assessment of financial, technological and economic LCOE input parameters. Technological Forecasting and Social Change 2016;104:89-101.

[18] Vazquez A, Iglesias G. Should tidal stream energy be publicly funded? Evidence from a choice experiment study. 11 th European Wave and Tidal Energy Conference (EWTEC), 2015, Nantes, France.

[19] Vazquez A, Iglesias G. Public perceptions and externalities in tidal stream energy: A valuation for policy making. Ocean Coast Manage 2015;105:15-24.

[20] Marine Current Turbines Ltd. Online:

http://www.marineturbines.com/3/news/article/38/dnv_confirms_seagen_s_powerful_perform ance.

[21] Renewable UK. Wave and Tidal Energy in the UK. Conquering Challenges, Generating Growth. Issue 2 2013; Online: file:///C:/Users/\%C3\%81ngela/Downloads/ruk13-008-8__wave_and_tidal_soi.pdf.

[22] Delft 3D. https://www.deltares.nl/en/software/delft3d-4-suite/.

[23] Carballo R, Iglesias G, Castro A. Numerical model evaluation of tidal stream energy resources in the Ría de Muros (NW Spain). Renewable Energy 2009;34:1517-24.

[24] Pacheco A, Ferreira Ó, Carballo R, Iglesias G. Evaluation of the production of tidal stream energy in an inlet channel by coupling field data and numerical modelling. Energy 2014;71:104-17.

[25] Ramos V, Carballo R, Álvarez M, Sánchez M, Iglesias G. Assessment of the impacts of tidal stream energy through high-resolution numerical modeling. Energy 2013;61:541-54.

[26] Dushaw BD, Egbert GD, Worcester PF, Cornuelle BD, Howe BM, Metzger K. A TOPEX/POSEIDON global tidal model (TPXO.2) and barotropic tidal currents determined from long-range acoustic transmissions. Prog Oceanogr 1997;40:337-67.

[27] Ramos V, Carballo R, Sanchez M, Veigas M, Iglesias G. Tidal stream energy impacts on estuarine circulation. Energy Conversion and Management 2014;80:137-49.

[28] Sanchez M, Carballo R, Ramos V, Iglesias G. Floating vs. bottom-fixed turbines for tidal stream energy: A comparative impact assessment. Energy 2014;72:691-701.

[29] BODC. British Oceanographic Data Centre. http://www.bodc.ac.uk/ 
[30] Sanchez M, Carballo R, Ramos V, Iglesias G. Tidal stream energy impact on the transient and residual flow in an estuary: A 3D analysis. Appl Energy 2014;116:167-77.

[31] NREL. http://www.nrel.gov/docs/fy12osti/51946.pdf.

[32] Malki R, Masters I, Williams AJ, Nick Croft T. Planning tidal stream turbine array layouts using a coupled blade element momentum - computational fluid dynamics model. Renewable Energy 2014;63:46-54.

[33] Denny E. The economics of tidal energy. Energy Policy 2009;37(5):1914-1924.

[34] Astariz S, Vazquez A, Iglesias G. Evaluation and comparison of the levelized cost of tidal, wave and offshore wind energy. Journal of Renewable and Sustainable Energy 2015;7.

[35] Vazquez A, Iglesias G. Device interactions in reducing the cost of tidal stream energy. Energy Conversion and Management 2015;97:428-38.

[36] Carbon Trust. Accelerating Marine Energy. The potential for cost reduction - insights from the Carbon Trust Marine Energy Accelerator. Carbon Trust 2011;CTC797.

[37] Serrano Gonzalez J, Burgos Payan M, Riquelme Santos J. An improved evolutive algorithm for large offshore wind farm optimum turbines layout. PowerTech, 2011 IEEE Trondheim 2011;pp 1-6.

[38] Astariz S, Perez-Collazo C, Abanades J, Iglesias G. Co-located wind-wave farms: economic assessment as a function of layout. Renewable Energy 2015;83:837-847.

[39] Astariz S, Iglesias G. The economics of wave energy: A review. Renewable and Sustainable Energy Reviews 2015;45:397-408.

[40] Bryden IG, Naik S, Fraenkel P, Bullen CR. Matching tidal current plants to local flow conditions. Energy 1998;23:699-709.

[41] Ernst \& Young. Cost of a financial support for wave, tidal stream and tidal range generation in the UK. A report for the Departament of Energy and Climate Change and the Scottish Government 2010.

[42] Azzellino A, Ferrante V, Kofoed JP, Lanfredi C, Vicinanza D. Optimal siting of offshore wind-power combined with wave energy through a marine spatial planning approach.

International Journal of Marine Energy 2013;3-4:e11-25.

[43] Möller B. Continuous spatial modelling to analyse planning and economic consequences of offshore wind energy. Energy Policy 2011;39:511-7.

[44] Ashley MC. Ecosystem service mapping in the Severn estuary and inner Bristol Channel. Report for NERC Marine Renewable Energy Knowledge Exchange Project. September 2014;RSPB and Plymouth Marine Laboratory, Plymouth 99pp. 
[45] Willis K, Scarpa R, Gilroy R, Hamza N. Renewable energy adoption in an ageing population: Heterogeneity in preferences for micro-generation technology adoption. Energy Policy 2011;39:6021-9.

[46] Neill SP, Hashemi MR, Lewis MJ. Optimal phasing of the European tidal stream resource using the greedy algorithm with penalty function. Energy 2014;73:997-1006.

[47] O'Rourke F, Boyle F, Reynolds A. Ireland's tidal energy resource; An assessment of a site in the Bulls Mouth and the Shannon Estuary using measured data. Energy Conversion and Management 2014;87:726-34.

[48] Giles J, Myers L, Bahaj A, Shelmerdine B. The downstream wake response of marine current energy converters operating in shallow tidal flows. World Renewable Energy Congress (Sweden) 8-13 May Linköping 2011.

[49] Hardisty J. The analysis of tidal stream power. John Wiley \& Sons, 2009.

[50] Hardisty J. The tidal stream power curve: a case study. Energy and Power Engineering 2012;4, 132-136.

[51] Yun Seng. Lim and Siong Lee. Koh. Marine Tidal Current Electric Power Generation: State of Art and Current Status, Renewable Energy, T J Hammons (Ed.), ISBN: 978-9537619-52-7, InTech, Available from: http://www.intechopen.com/books/renewableenergy/marine-tidal-current-electric-power-generation-state-ofart-and-current-status.

[52] Higgins P, Foley A. The evolution of offshore wind power in the United Kingdom. Renewable and Sustainable Energy Reviews 2014;37:599-612.

[53] Astariz S, Perez-Collazo C, Abanades J, Iglesias G. Co-located wind-wave farm synergies (Operation \& Maintenance): A case study. Energy Conversion and Management 2015;91:63-75.

[54] Ahmadian R, Olbert AI, Hartnett M, Falconer RA. Sea level rise in the Severn Estuary and Bristol Channel and impacts of a Severn Barrage. Comput Geosci 2014;66:94-105.

[55] Fairley I, Ahmadian R, Falconer RA, Willis MR, Masters I. The effects of a Severn Barrage on wave conditions in the Bristol Channel. Renewable Energy 2014;68:428-42. 
Figure 10. Tidal stream energy hotspots.

Figure 1. The study area (Bristol Channel).

Figure 4. Breakdown of capital costs. conservation areas [44]. constraints.

Figure 2. New tool: workflow [ $d$, water depth; $v_{i}(t)$, temporal series of flow velocity; $v_{c i}$, cutin velocity; $v_{c o}$, cut-off velocity; $v_{r}$, rated velocity; $D$, diameter; $C_{p}$, power coefficient; $n$, number of turbines; $C A P E X$, capital expenditures; OPEX, operational expenditures; $L C O E$, levelised cost of energy; MoD, ministry of defence; subscript $i$ refers to grid cell].

Figure 3. Tidal stream farm layout and spatial constraints.

Figure 5. Competing uses for tidal stream deployment at Bristol Channel: (a) shipping traffic; (b) submarine cabling and grid connection points; (c) MoD (ministry of defence) areas; (d)

Figure 6. Annual energy density (AED) in the Bristol Channel.

Figure 7. Calculation of technical potential, on the basis of annual energy density and spatial

Figure 8. Technical potential maps: (a) $C_{p}=0.30$; (b) $C_{p}=0.35$; (c) $C_{p}=0.40$ [boundary lines correspond to values: 5, 10, 20 and $60 \mathrm{GWh}$ per year].

Figure 9. Spatial distribution of the levelised cost of energy (LCOE), contour lines: (a) water depth (m); (b) distance to the shoreline (km); (c) mean spring velocity $\left(\mathrm{m} \mathrm{s}^{-1}\right)$. 
Table 1. Cost categories included in the model.

\begin{tabular}{|c|c|c|c|}
\hline Cost $(£)$ & Variables & Model & Source \\
\hline \multirow[t]{2}{*}{ Rotor costs $(£)$} & Rotor diameter $(D)$ & $n 80.388_{(2010)} D^{2.687}$ & [40] \\
\hline & $\begin{array}{l}\text { Number of converters } \\
\qquad(n)\end{array}$ & & \\
\hline $\begin{array}{c}\text { Foundation costs }(£ \\
\text { per MW) }\end{array}$ & Water depth $(d)$ & $\begin{aligned} \mathrm{d}(0-30 \mathrm{~m}) & \rightarrow 0.1875+1.2510^{-5} d^{3} \\
\mathrm{~d}(30-60 \mathrm{~m}) & \rightarrow 0.4375+510^{-5} d^{3} \\
\mathrm{~d}(>60 \mathrm{~m}) & \rightarrow 0.1875+0.02 d^{3}\end{aligned}$ & [37] \\
\hline Cable costs $(£)$ & $\begin{array}{l}\text { Distance to the shoreline } \\
\qquad(L)\end{array}$ & $169.79_{(2010)} L$ & [40] \\
\hline O\&M (£ per MW) & Installed capacity $(P)$ & 310000 P (MW) & [41] \\
\hline Other & $\begin{array}{l}\text { Remaining percentage of } \\
\text { CAPEX }\end{array}$ & $30 \%$ & [36] \\
\hline
\end{tabular}


Table 2. Hotspot areas for tidal stream applications.

\begin{tabular}{llllcl}
\hline $\begin{array}{l}\text { Hotspot } \\
\text { (group) }\end{array}$ & Point & $\begin{array}{l}\text { LCOE } \\
(£ \text { per kWh) })\end{array}$ & $\begin{array}{l}\text { Water } \\
\text { depth }(\mathrm{m})\end{array}$ & $\begin{array}{l}\text { Distance to the } \\
\text { shoreline }(\mathrm{km})\end{array}$ & $\begin{array}{l}\text { Area } \\
\left(\sim \mathrm{km}^{2}\right)\end{array}$ \\
\hline A & A1 & $<0.25$ & $<40$ & $<10$ & 75.25 \\
& A2 & $<0.18$ & $<30$ & $<5$ & 12.5 \\
& A3 & $<0.20$ & $<20$ & $<20$ & 119 \\
& A4 & $<0.18$ & $<15$ & $<8$ & 24.5 \\
B & B1 & $<0.20$ & $<20$ & $<10$ & 28 \\
& B2 & $<0.10$ & $<20$ & $<10$ & 125.5 \\
\hline
\end{tabular}




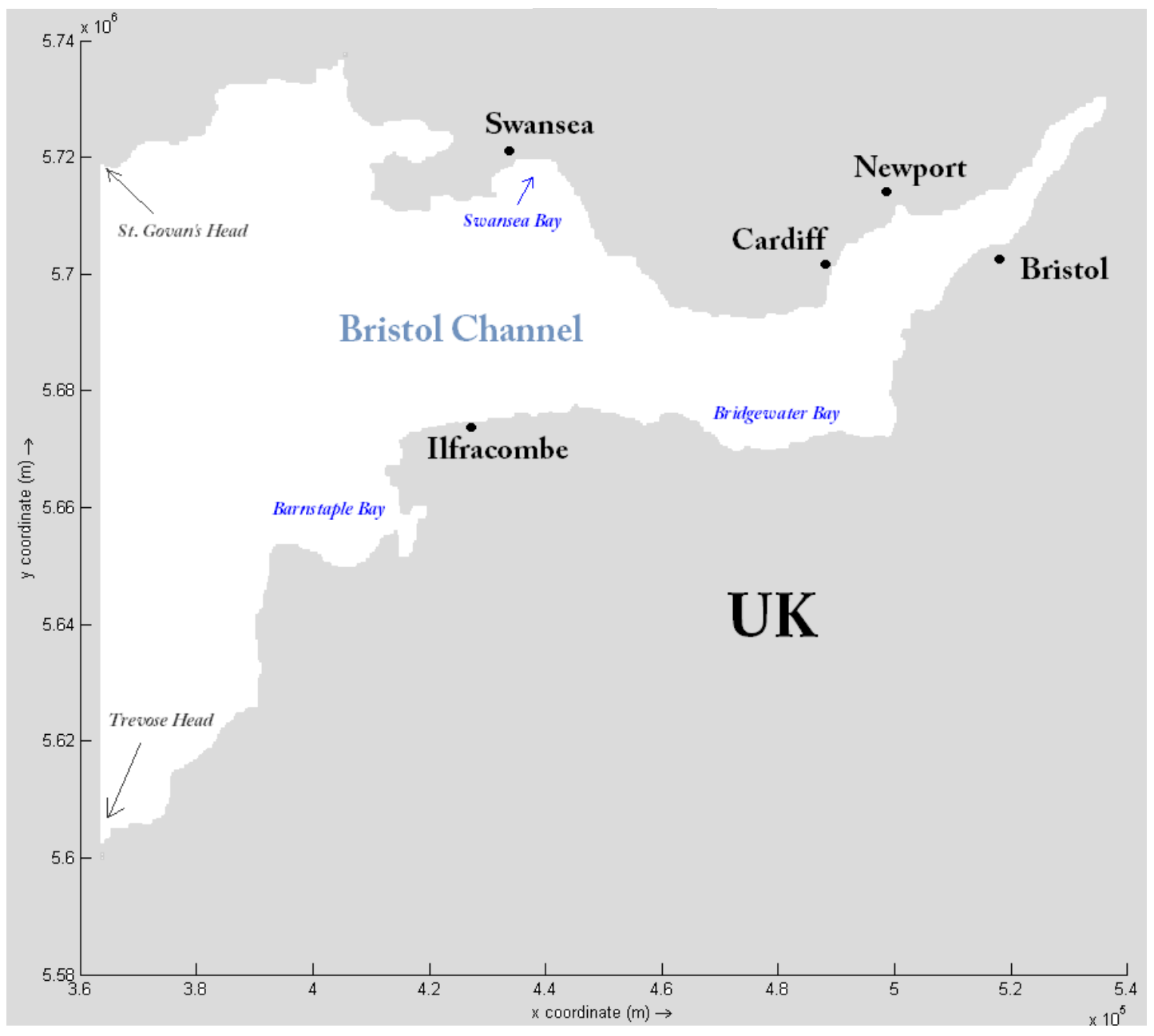




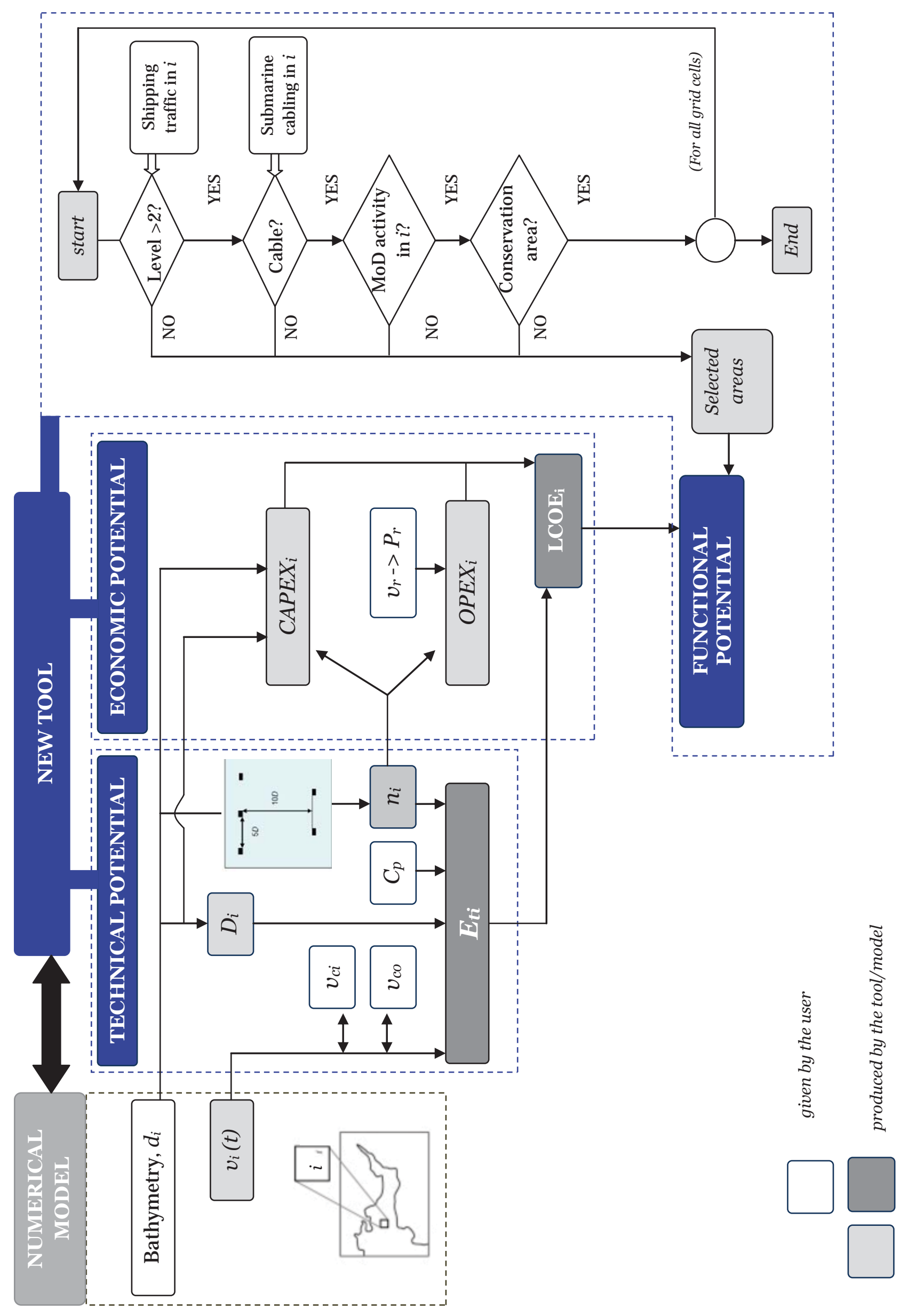

N
믄
은 
Figure 3

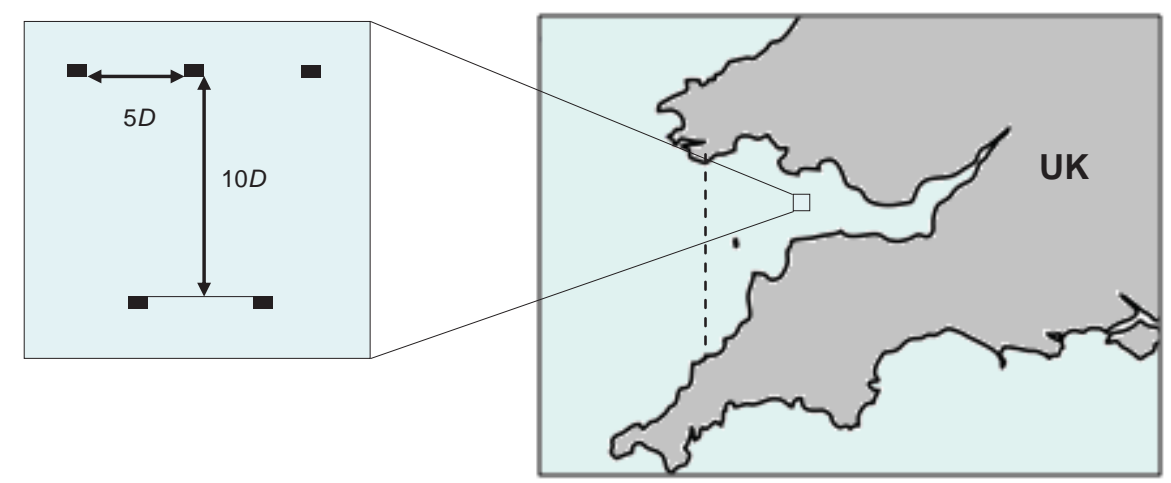


Figure 4

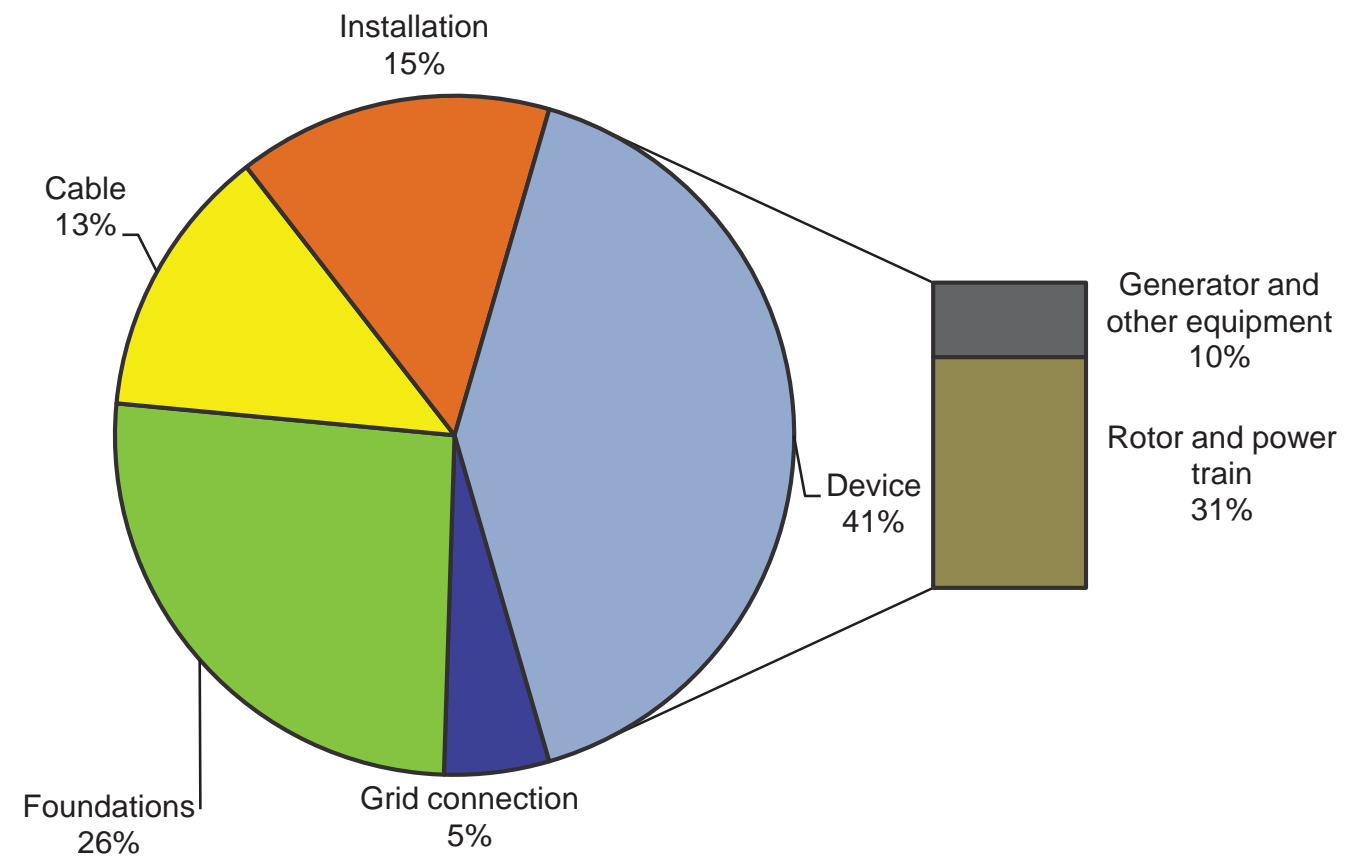



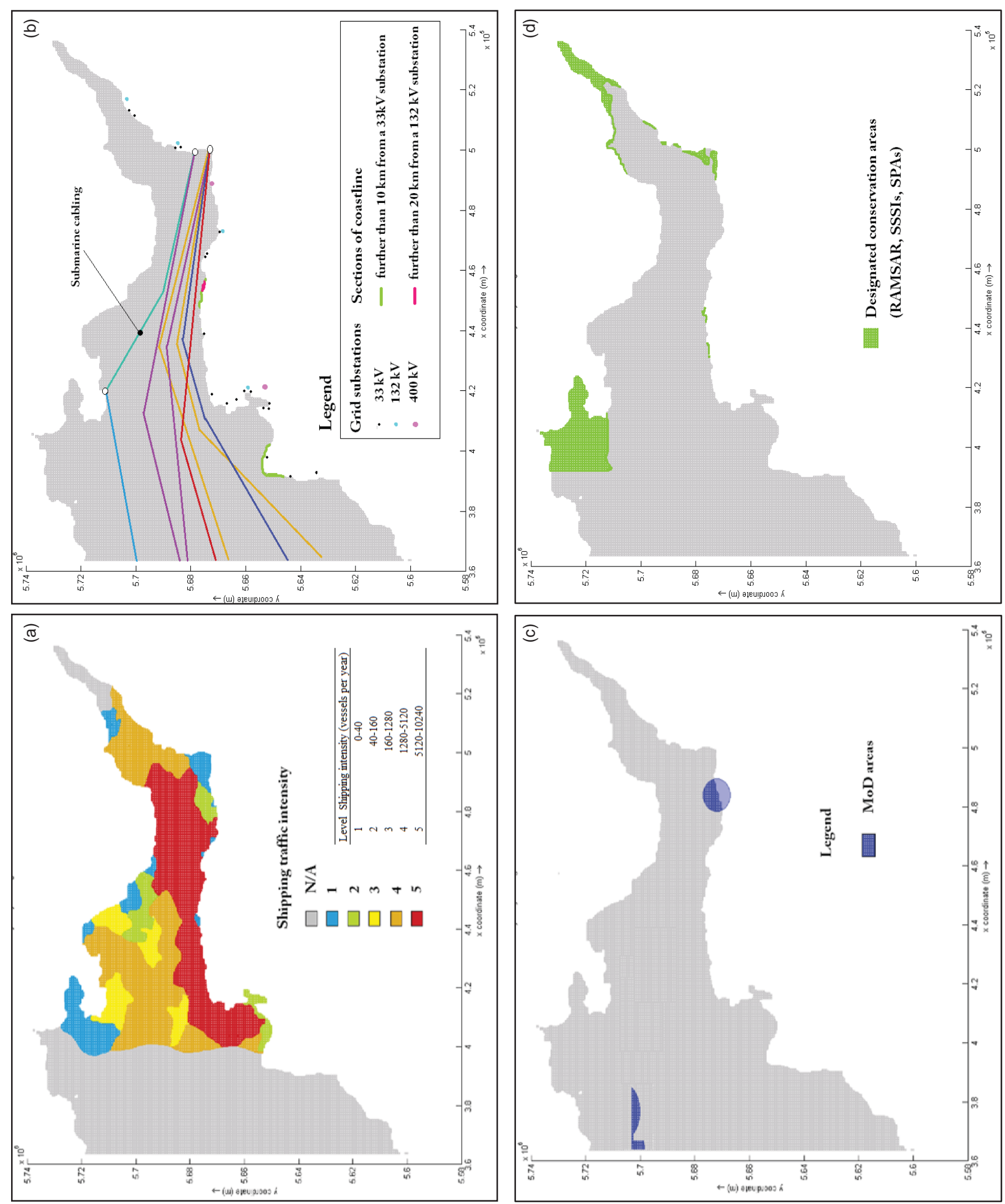

م
$\frac{0}{5}$
$\frac{0}{5}$
$\frac{0}{4}$ 
Figure 6

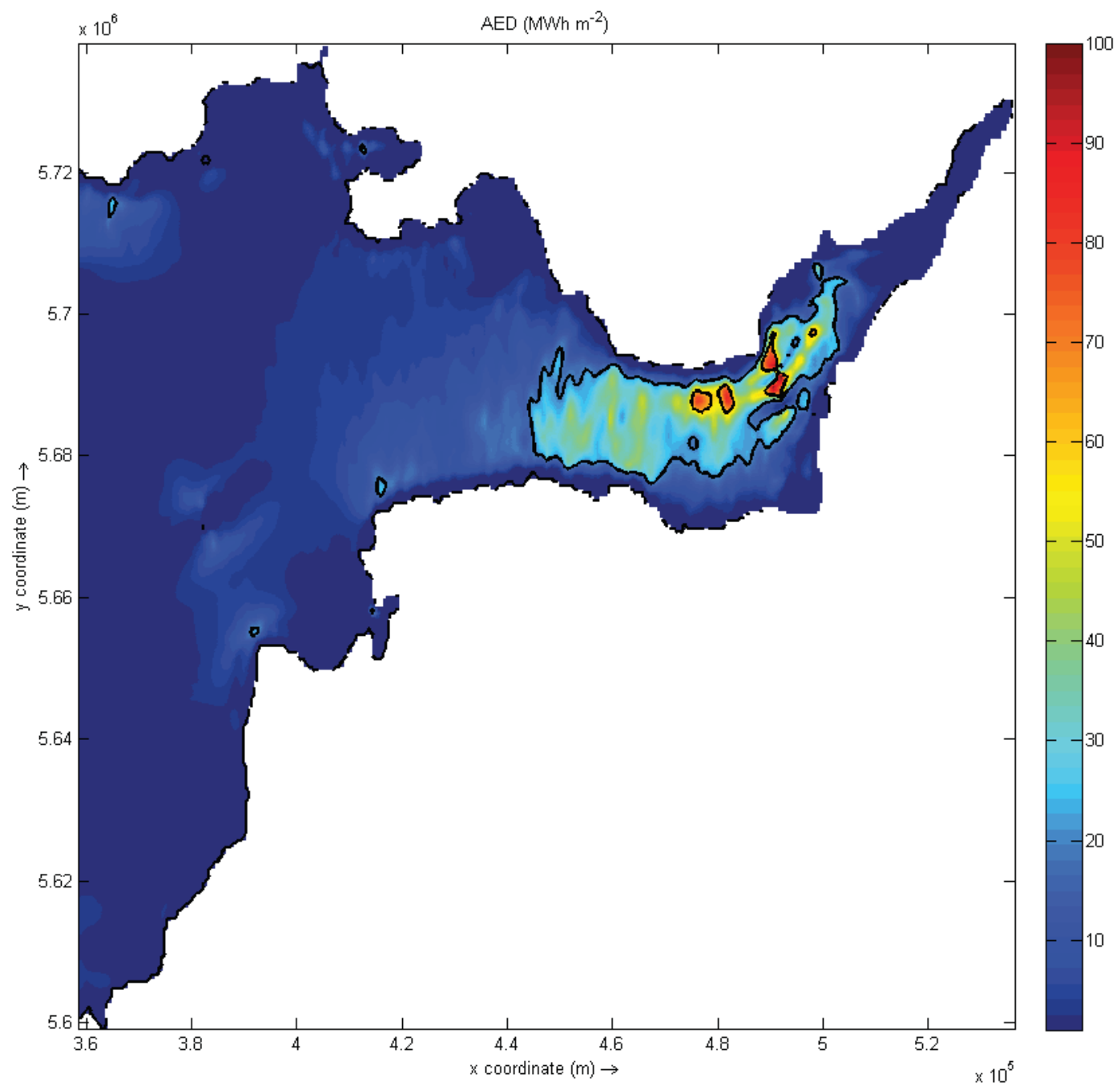



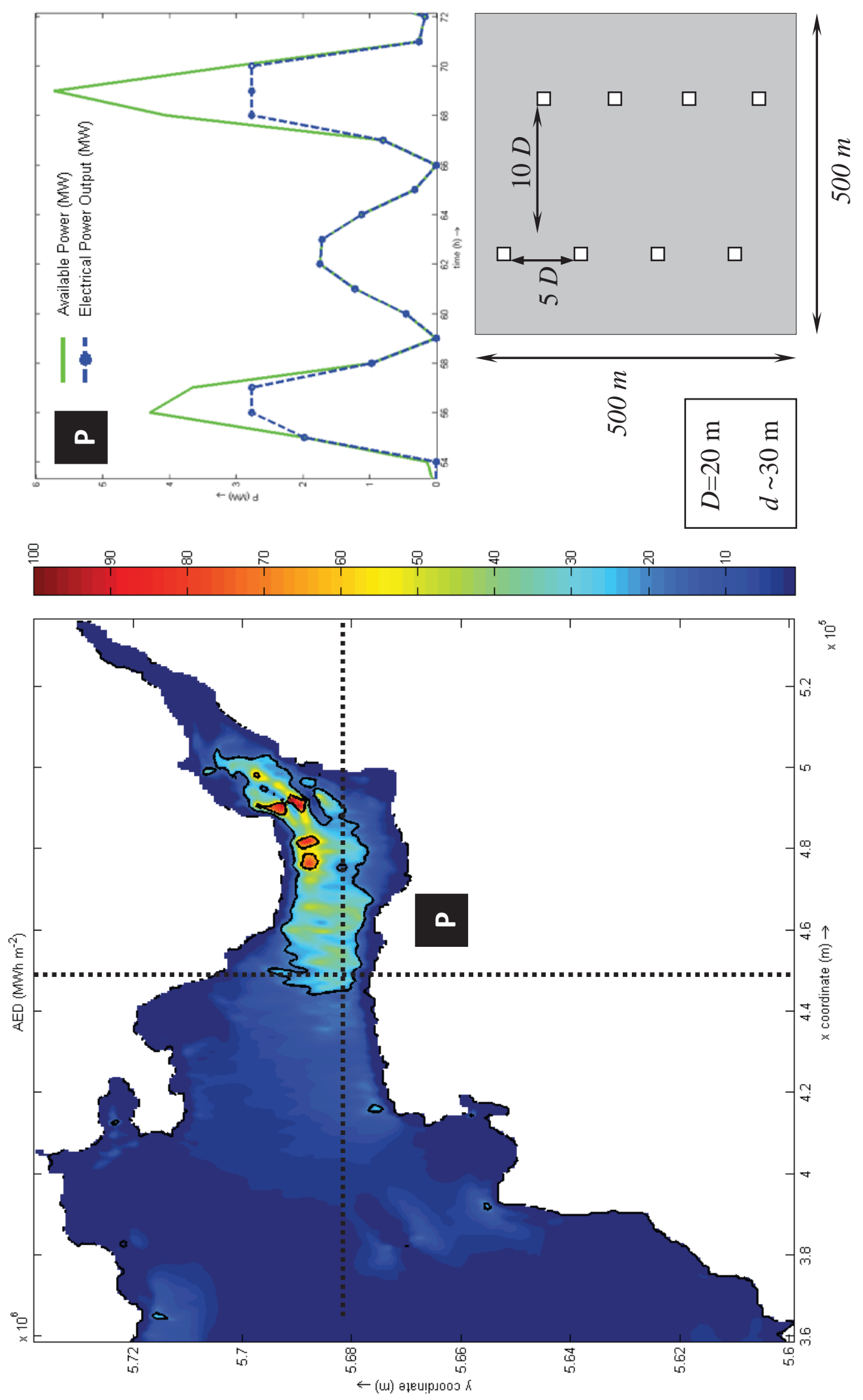

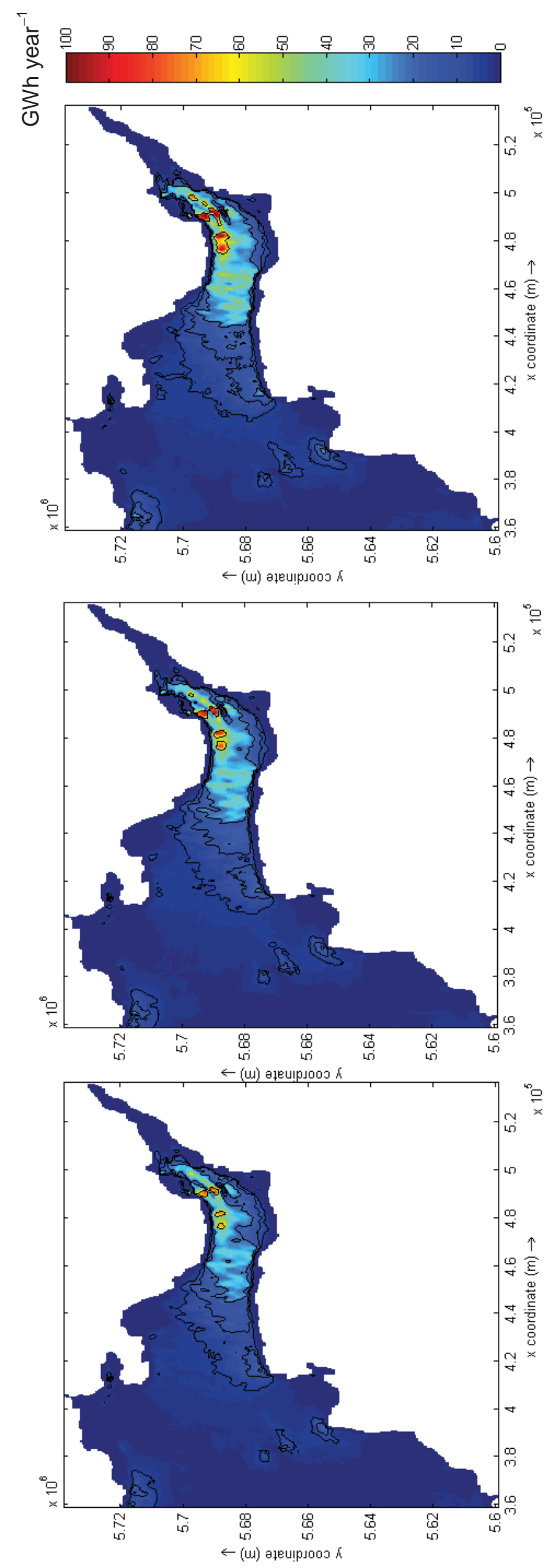


$$
\frac{2}{2}
$$



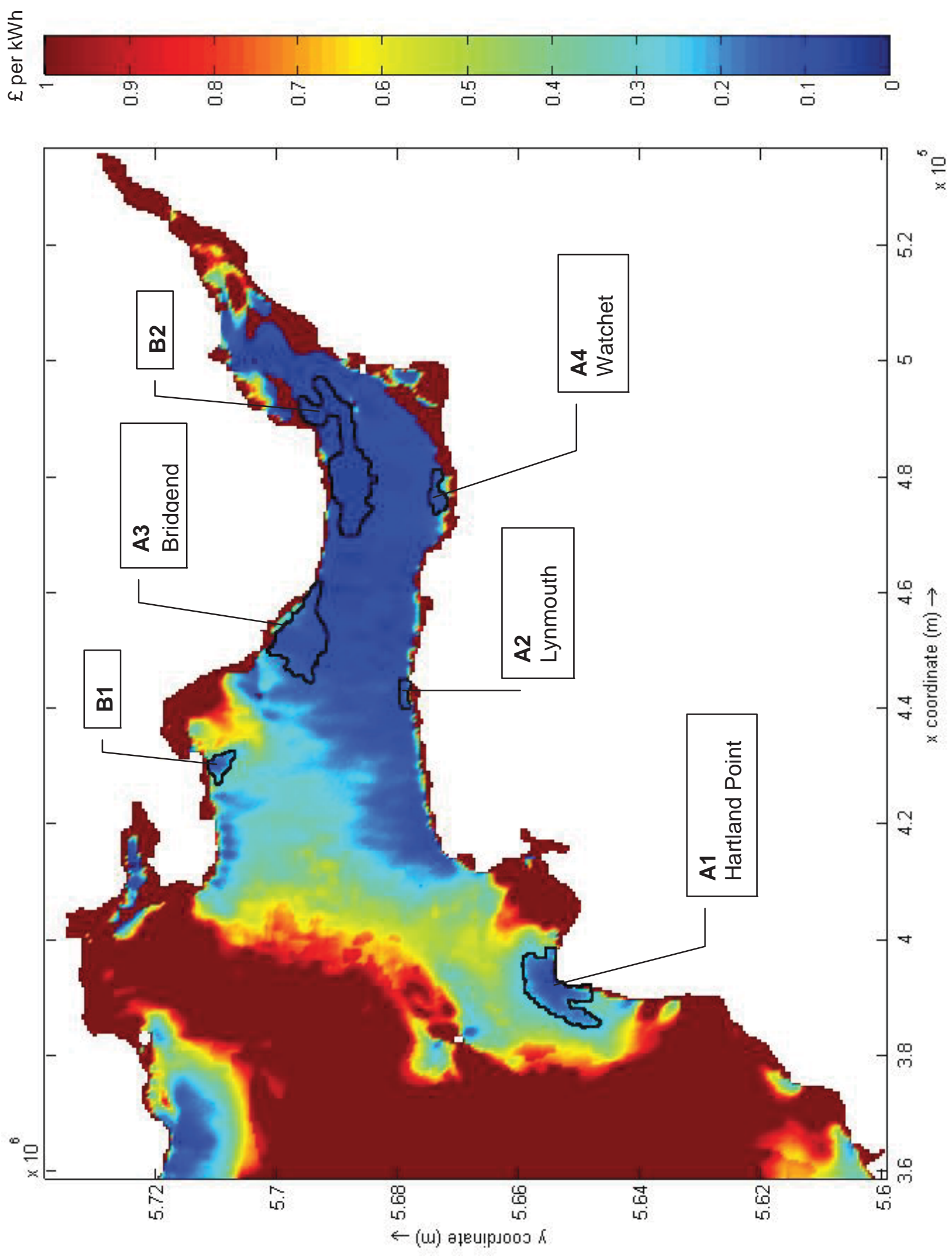